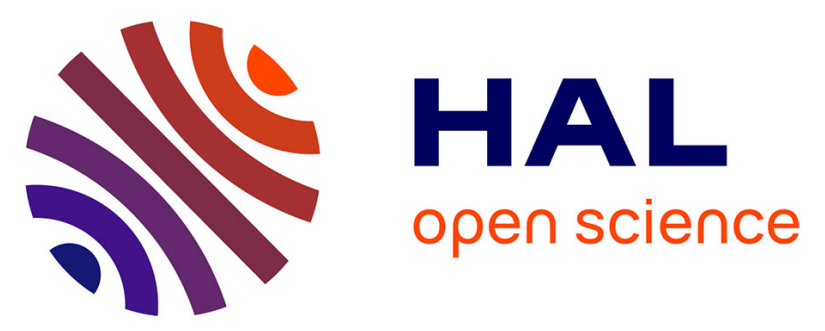

\title{
Design and Synthesis of Hybrid PEGylated Metal Monopicolinate Cyclam Ligands for Biomedical Applications
}

Fatima Aouidat, Zakaria Halime, Rosalba Moretta, Ilaria Rea, Stefania Filosa, Stella Donato, Rosarita Tatè, Luca de Stefano, Raphaël Tripier, Jolanda Spadavecchia

\section{To cite this version:}

Fatima Aouidat, Zakaria Halime, Rosalba Moretta, Ilaria Rea, Stefania Filosa, et al.. Design and Synthesis of Hybrid PEGylated Metal Monopicolinate Cyclam Ligands for Biomedical Applications. ACS Omega, 2019, 4 (2), pp.2500-2509. 10.1021/acsomega.8b03266 . hal-02337561

\section{HAL Id: hal-02337561 https://hal.science/hal-02337561}

Submitted on 29 Oct 2019

HAL is a multi-disciplinary open access archive for the deposit and dissemination of scientific research documents, whether they are published or not. The documents may come from teaching and research institutions in France or abroad, or from public or private research centers.
L'archive ouverte pluridisciplinaire HAL, est destinée au dépôt et à la diffusion de documents scientifiques de niveau recherche, publiés ou non, émanant des établissements d'enseignement et de recherche français ou étrangers, des laboratoires publics ou privés. 


\title{
Design and Synthesis of Hybrid PEGylated Metal Monopicolinate Cyclam Ligands for Biomedical Applications
}

\author{
Fatima Aouidat, ${ }^{\dagger}$ Zakaria Halime, ${ }^{\ddagger}$ Rosalba Moretta, ${ }^{\S}$ Ilaria Rea, ${ }^{\S}$ Stefania Filosa, "Stella Donato,"
}

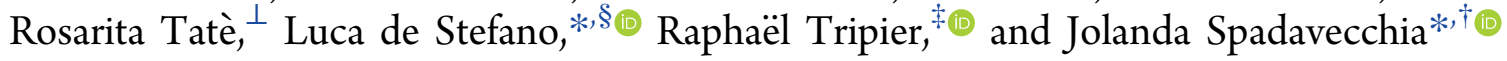

${ }^{\dagger}$ CNRS, UMR 7244, CSPBAT, Laboratoire de Chimie, Structures et Propriétés de Biomateriaux et d'Agents Therapeutiques Université Paris 13, 1 rue Chablis 93000, Sorbonne Paris Cité, 93000 Bobigny, France

${ }^{\ddagger}$ Universitè de Brest, UMR-CNRS 6521/IBSAM, UFR Sciences et Techniques, 6 Avenue Victor le Gorgeu, C.S. 93837, 29238 Brest, France

${ }^{\S}$ Institute for Microelectronics and Microsystems, Unit of Naples, CNR, Via P. Castellino 111, 80131 Naples, Italy

"Institute of Biosciences and Bioresources (IBBR), National Research Council (CNR), Naples, Italy-IRCCS, Neuromed, Via Università, 133, 80055 Pozzilli, Isernia, Italy

${ }^{\perp}$ Institute of Genetics and Biophysics “Adriano Buzzati-Traverso”, CNR, Via P. Castellino 111, 80131 Naples, Italy

\section{Supporting Information}

ABSTRACT: In this study, we report, for the first time, the synthesis of two original nanosystems, based on gold $\mathrm{Au}(\mathrm{III})$ and copper $\mathrm{Cu}(\mathrm{II})$ : simple gold-copper nanoparticles ( $\left.\mathrm{Cu}^{0} \mathrm{AuNPs}\right)$ and enriched monopicolinate cyclam (L1) $-\mathrm{Cu}(\mathrm{II})-\mathrm{Au}(\mathrm{III})$ complex (L1@Cu ${ }^{2+A u N P s) . ~ T h e ~ t w o ~ n a n o m a t e r i a l s ~ d i f f e r ~}$ substantially by the chelation or not of the $\mathrm{Cu}(\mathrm{II})$ ions during the NPs synthesis process. The two hybrid nanoparticles $\left(\mathrm{Cu}^{0} \mathrm{AuNPs}\right.$; L1@Cu ${ }^{2+}$ AuNPs $)$ were deeply studied from the chemical and physical point of view, using many different analytical techniques such as Raman and UV-vis spectroscopy, electron transmission microscopy, and dynamic light scattering. Both nanosystems show morphological and good chemical stability at $\mathrm{pH} 4$ values and in physiological conditions during 98

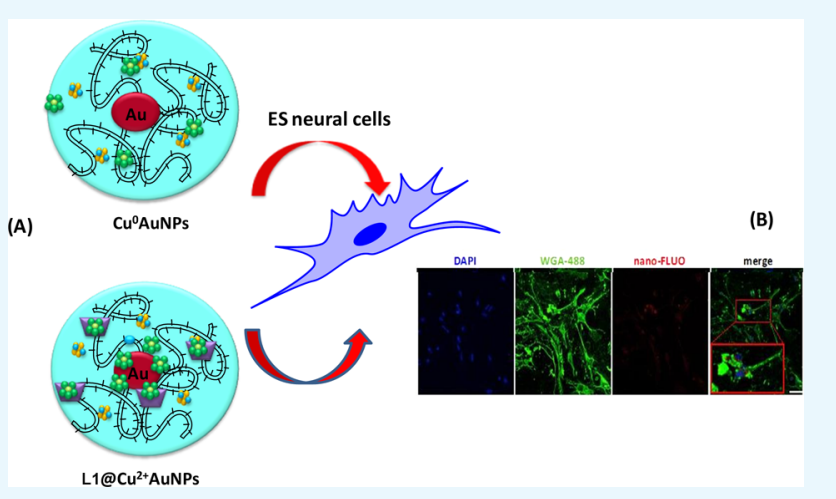
h. Undifferentiated and neural differentiated murine embryonic stem cells were used as a model system for in vitro experiments to reveal the effects of NPs on these cells. The comparative study between $\mathrm{Cu}^{0} \mathrm{AuNPs}$ and $\mathrm{L} 1 @ \mathrm{Cu}^{2+} \mathrm{AuNPs}$ highlights that copper chelated in its +2 oxidation state in the NPs is more functional for biological application.

\section{INTRODUCTION}

Hybrid metal-organic nanoparticles (NPs) have been recently used as diagnostic and therapeutic tools to better understand, detect, and treat several human diseases. ${ }^{1,2}$ Metal-based NPs have been proposed as performing contrast agents that can increase signal intensity in magnetic resonance imaging (MRI) and positron emission tomography imaging, or as nanovectors for specifically delivering of drugs inside cells.

The insertion of copper $(\mathrm{Cu})$, especially as $\mathrm{Cu}^{2+}$ atoms, in NPs structures is still challenging because it has an important impact in many scientific fields from catalysis and plasmonics up to nanomedicine applications. ${ }^{3-6}$ Because cationic metals take part in biological systems (charge balancing, stabilizing structures, reactions catalyzing, and so on), copper ions should be chelated to avoid the in vivo metal releasing that could induce several undesirable effects.

Biocompatible copper(II) chelators are commonly those that yield thermodynamically stable and kinetically inert complexes so that transchelation of $\mathrm{Cu}$ due to competition with other biological ligands, metals, or reductive media is avoided. Among known copper(II) ligands, azacycloalkanes present the highest complexion properties. ${ }^{7}$ By $\mathrm{N}$-functionalization of their properties, especially in terms of kinetic of formation (maximizing the complexation rate) and dissociation (decreasing of the decomplexation rate), could also be improved. A special category of rigid tetraazamacrocycles, indicated as cross-bridged derivatives, has been the source of great interest because of the outstanding behavior in complexing different metals, including copper(II). ${ }^{8-10}$ Due to an ethylene linker connecting two opposite nitrogen atoms of the macrocycle, these ligands produced some of the most inert metal complexes ever reported.

We recently have published a size-adapted azamacrocycle, the cb-telpa chelator ${ }^{11-13}$ (see its structure in Figure 1), which combines all the criteria for $\mathrm{Cu}(\mathrm{II})$ chelation, i.e., the presence of cyclam, the ethylene cross bridge and an efficient chelating

Received: December 2, 2018

Accepted: December 28, 2018

Published: February 1, 2019 


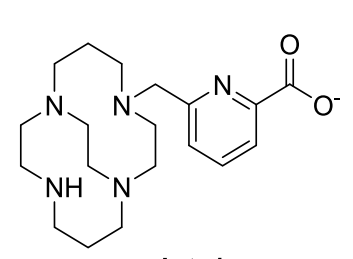

cb-te1pa

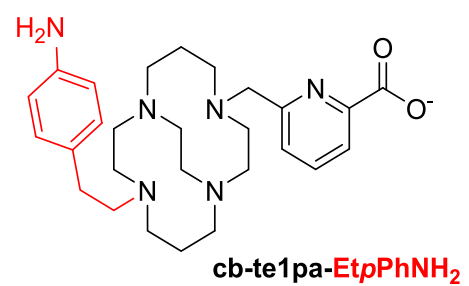

cb-te1pa-EtpPhNH
Figure 1. Ligand cb-telpa and its bifunctionalized analogue cb-telpaEtp $\mathrm{PhNH}_{2}$.

functionalization, in particular the methyl pycolinic acid, a cross-bridged cyclam bearing a methylpycolinate pendant. This compound was able to chelate copper(II) after fast complexation, yielding a highly thermodynamical stable and an exceptionally inert product, even if $\mathrm{Cu}$ was in the $(+1)$ oxidation state. Due to the presence of a secondary amine, an additional functional group, which could be dedicated to the conjugation of cb-telpa with a solid support, was then easily added as an aniline moiety. To preserve a sufficient distance between the coordination center and the anchoring point, an ethylene linker was chosen to take away the aromatic part. The bifunctionalized analogue cb-telpa-Et $p \mathrm{PhNH}_{2}(\mathrm{~L} 1)$ was then the final $\mathrm{Cu}$ ligand (Figure 1).

In the present study, we synthesized two new nanoparticle systems including gold and copper wrapped in their structure. In the first case, $\mathrm{Cu}$ (II) was introduced as "free" cation and in the second case, in its $[\mathrm{Cu}(\mathrm{cb}-\text { telpa })]^{+}-\mathrm{Et} p \mathrm{PhNH}_{2}$ chelated form $\left(\mathrm{LlCu}^{+}\right)$. According to the NPs formation procedure, the first material included $\mathrm{Cu}^{0}$, whereas the second one the $\mathrm{Cu}^{2+}$ chelated ions. Characterizations were performed to investigate the structure of both NPs. Potential cytotoxic effects was evaluated in vitro on undifferentiated and neural differentiated embryonic stem cells (ESCs). ESCs can be used as a model system in basic research, drug discovery, biomedical applications, and nanotechnology because they combine the potential of unlimited self-renewal with the ability to differentiate into a wide range of tissue-specific cells.

\section{RESULTS AND DISCUSSION}

2.1. Formation Mechanisms of Au-Cu-Based Nanoparticles. Peculiar molecular interactions between organic compounds and metal chlorides was extensively studied for many biochemical and physical applications. ${ }^{19-22}$ The aim of this study was to use a copper-gold chloride blend as the building blocks of hybrid nanoparticles under specific conditions of reaction. For this purpose, in the first step, we mixed $\mathrm{HAuCl}_{4} \cdot 3 \mathrm{H}_{2} \mathrm{O}$ and $\mathrm{CuCl}_{2} \cdot 6 \mathrm{H}_{2} \mathrm{O}$ in water solution at room temperature under specific $\mathrm{pH}$ conditions (Scheme 1). The formation of $\mathrm{Au}-\mathrm{Cu}$ blend (Figure $\mathrm{S} 1$ in the Supporting Information) could be deduced by looking at the fingerprints of each single solution $\left(\mathrm{HAuCl}_{4} \cdot 3 \mathrm{H}_{2} \mathrm{O}, \mathrm{CuCl}_{2} \cdot 6 \mathrm{H}_{2} \mathrm{O}\right)$ present in the $\mathrm{UV}$-vis spectrum of their mix $(\mathrm{Au}-\mathrm{Cu})$. In particular, the UV-vis spectrum of $\mathrm{HAuCl}_{4} \cdot 3 \mathrm{H}_{2} \mathrm{O}$ (black line in Figure $\mathrm{S} 1)$ showed typical signatures with two prominent peaks at 256 and $290 \mathrm{~nm}$. The UV-vis spectrum of $\mathrm{CuCl}_{2} \cdot 6 \mathrm{H}_{2} \mathrm{O}$ solution showed a peak at $256 \mathrm{~nm}$, a small peak at $280 \mathrm{~nm}$ and a broadened peak at $800 \mathrm{~nm}$ (red line in Figure S1). When $\mathrm{CuCl}_{2} \cdot 6 \mathrm{H}_{2} \mathrm{O}$ was added to $\mathrm{HAuCl}_{4} \cdot 3 \mathrm{H}_{2} \mathrm{O}$ solution, the UVvis spectrum (blue line in Figure $\mathrm{S} 1$ ) slightly changed. Main difference in the spectra was due to the increase and the shift of the peak from 280 to $320 \mathrm{~nm}$ due to electronic transitions. Moreover, the dramatic decrease of the peak at $800 \mathrm{~nm}$ confirmed that the hybrid system $(\mathrm{Au}-\mathrm{Cu})$ was obtained. ${ }^{20}$

Raman spectroscopy (Figure S1B) also displayed the peak at $254 \mathrm{~cm}^{-1}$ due to $\mathrm{Cu}-\mathrm{Au}-\mathrm{Cl}$ and $\mathrm{Cu}-\mathrm{OH}$ stretching, which were assigned to vibrations mainly within the coordination sphere of $\mathrm{Cu}^{2+}$, confirming the successful reaction. ${ }^{20}$

Figure S2a,b in the Supporting Information shows the localized surface plasmon (LSP) resonance spectra before and after incubation of $\mathrm{HAuCl}_{4}$ mixed to $\mathrm{CuCl}_{2}$ under specific conditions ( $\mathrm{pH}$ : 4.0-7.0-9.0; time: $96 \mathrm{~h}$ ). At $\mathrm{pH}$ 4, we observed an increase in the peak intensity at $256 \mathrm{~nm}$ probably due to $\mathrm{CuCl}_{2}$ fingerprint associated to $\mathrm{AuCl}_{2}$ ions upon complexation. The increase of the peak at $800 \mathrm{~nm}$ confirmed the reaction under acidic conditions. A different behavior was observed in the case of $\mathrm{pH} 7$ and $\mathrm{pH} 9$ (Figure $\mathrm{S} 2$ panel b), in which the LSP bands could not be observed any more after incubation at $\mathrm{pH} 7$ and 9 for $96 \mathrm{~h}$. This spectroscopic behavior during $\mathrm{pH}$ release gave evidence of the change of reagent conformation when it was encapsulated into gold nanoparticles.

2.2. Formation Mechanism of $\mathrm{Cu}^{0}-\mathrm{AuNPs}$ and $\mathrm{L} 1 @$ $\mathrm{Cu}^{2+}-$ AuNPs. Recently, Spadavecchia et al. have designed and produced different novel hybrid nanomaterials based on gold, polymers, proteins, and drug complexes by original chemical synthetic methodology. ${ }^{17,23,24}$ These authors have investigated the formation mechanism and the competition effect between various capping agents on the growth process of hybrid nanoparticles. ${ }^{25}$ Some chemical-physical characterizations and the analysis of biological activity have fully elucidate that conformation change of biomolecules (i.e., polymer, drug, protein) during the formation of hybrid gold nanostructures by chelation had a good impact on its therapeutic activity. In case of $\mathrm{Cu}$, other authors showed that copper influenced the optical plasmonic features of the gold nanorods when incorporated in

Scheme 1. Schematic Representation of the Hybrid Blend ( $\mathrm{Au}-\mathrm{Cu}$ )
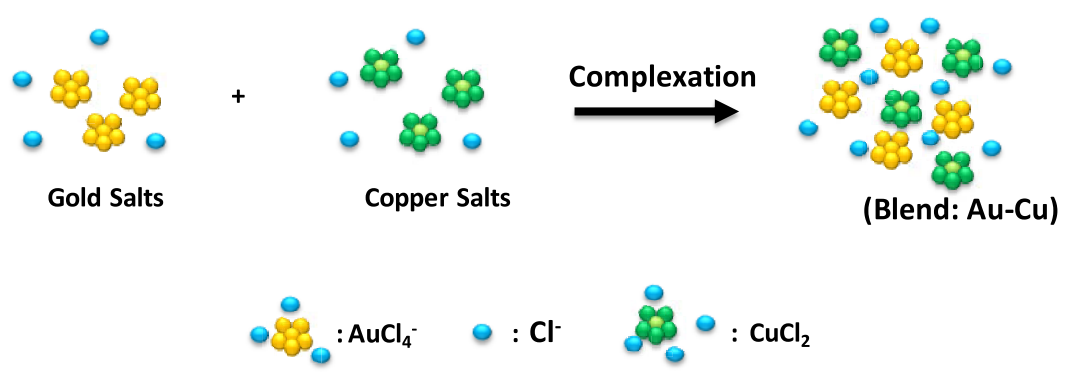

${ }^{a}$ Please note that drawings are not in scale and are not intended to be representative of the full samples composition. 
Scheme 2. Schematic Representation of the Synthesis of $\mathrm{Cu}^{0}-\mathrm{AuNPs}$ via a Two-Step Process ${ }^{a}$

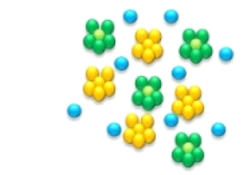

Hybrid blend: Au-Cu

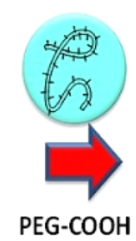

Stacking
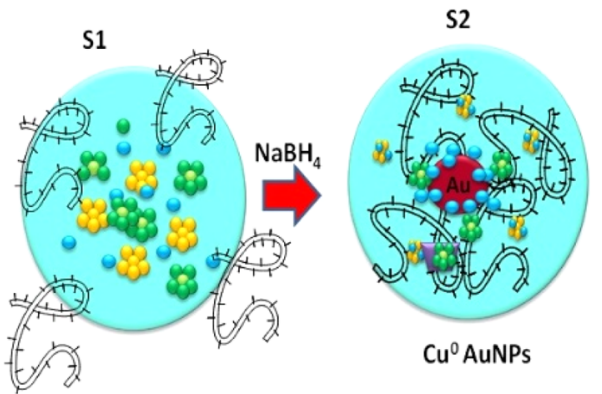

${ }^{a}$ Please note that drawings are not in scale and are not intended to be representative of the full samples composition.

Scheme 3. Schematic Representation of the Synthesis of L1@Cu ${ }^{2+}-A u N P s$ via a Three-Step Process ${ }^{a}$

S1

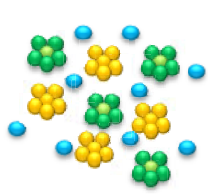

Hybrid Complex: $\mathrm{Au}-\mathrm{CuCl}_{2}$
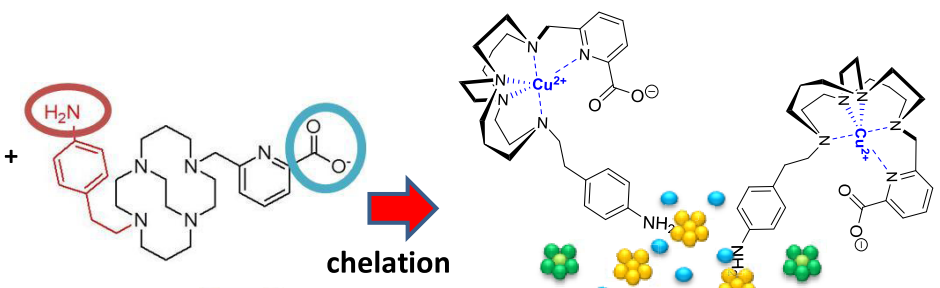

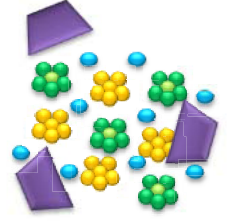

L1@AuCuCl
L1:

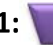

Stacking

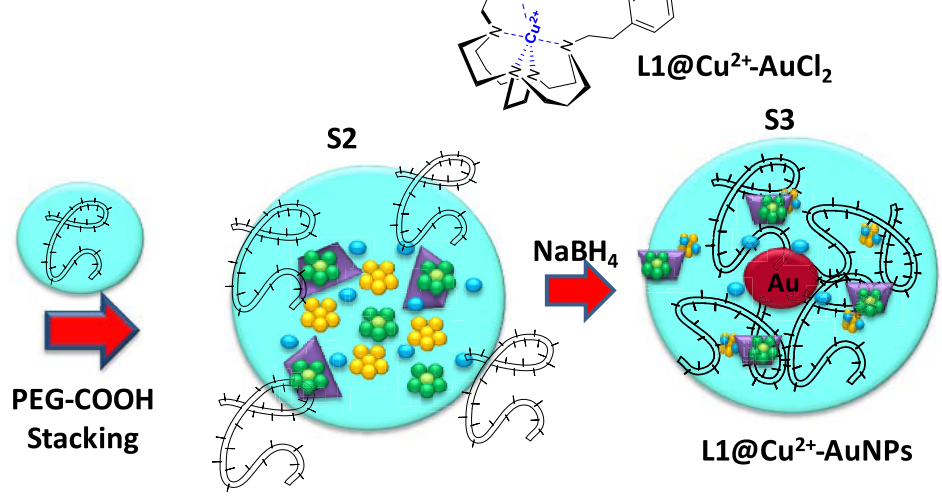
chelation

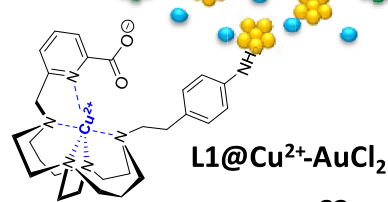

${ }^{a}$ Please note that drawings are not in scale and are not intended to be representative of the full samples composition.

the growth solution during the seed-mediated synthesis. ${ }^{4}$ The aim of this research was to prove the formation of stable hybrid complexes based on PEGylated $\mathrm{Au}-\mathrm{Cu}$ and PEGylated L1@ $\mathrm{Au}-\mathrm{Cu}$, respectively. Some synthesis procedures of $\mathrm{Cu}^{2+}$ AuNPs by chemical and physical adsorption using chelator linkers can be found in recent literature. ${ }^{19,26}$ The main difference with previously reported synthetic procedures was that L1 ligand totally bound $\mathrm{Cu}^{2+}$ and participated in the stabilization of PEGylated $\mathrm{Cu}^{2+}-\mathrm{AuNPs}$ via electrostatic interaction between their amino groups with chloride copper-auric ions. Moreover, the chelation of $\mathrm{Cu}^{2+}$ avoided its reduction during the NPs synthesis process. Indeed, the macrocyclic chelation added extremely high stability to the copper(I) complex and allowed the stability of the chelate all along the formation of the final material.

The formation of hybrid gold-copper NPs from $\mathrm{Cu}-\mathrm{Au}$ mixture is summarized in Schemes 2 and 3. Step (1) was the complexation of solutions $\mathrm{CuCl}_{2}-\mathrm{AuCl}_{4}^{-}$and generation of copper-gold clusters (see Scheme 2). Step (2) is the initial reduction of $\mathrm{Au}(\mathrm{III})$ ions by dicarboxylic acid-terminated poly(ethylene glycol) (PEG) that adsorbed onto $\mathrm{Cu}-\mathrm{Au}$ clusters (Scheme 2); the last step (3) is the reduction of metal ions in that vicinity and the growth of hybrid gold particles $\left(\mathrm{Cu}^{0}-\mathrm{AuNPs}\right)$ together with the colloidal stabilization due to the molecules of PEG polymers.

In this frame, L1 ligands take part in the reaction, thanks to their amino group onto copper-gold clusters in which copper was kept in oxidation state $\mathrm{Cu}^{2+}$ and chelated with them (Scheme 3). The positive charge of the amino group onto L1 ligand in water solutions showed strong electrostatic interaction with negatively charged $\mathrm{Cu}^{2+}-\mathrm{AuCl}$ ions and formed a complex L1@ $\mathrm{Cu}^{2+}-\mathrm{AuCl}$ that played a final role in the growth of NPs. A large excess of L1 ligand in the mixture was required to chelate completely all $\mathrm{Cu}^{2+}$. The addition of diacid PEG improved the kinetics of reduction by complexation of $\mathrm{Cu}-\mathrm{Au}$ ions, ${ }^{27,25}$ just tuning the growth process of hybrid nanoparticles. During the S2 phase (Scheme 3), L1@ $\mathrm{Cu}^{2+}-\mathrm{AuCl}$ complexes migrated through PEG molecules. Thus, an appreciable amount of complexes diffused and were captured inside the PEG layer via a mechanism similar to the other ligand complexes loaded onto nanostructures. ${ }^{16,23,28}$ Based on previously research studies, ${ }^{29}$ we suppose that when PEG was added to the $\mathrm{L} 1 @ \mathrm{Cu}^{2+}-\mathrm{AuCl}$, the PEG initially was bound to hybrid complex in a mushroom conformation 

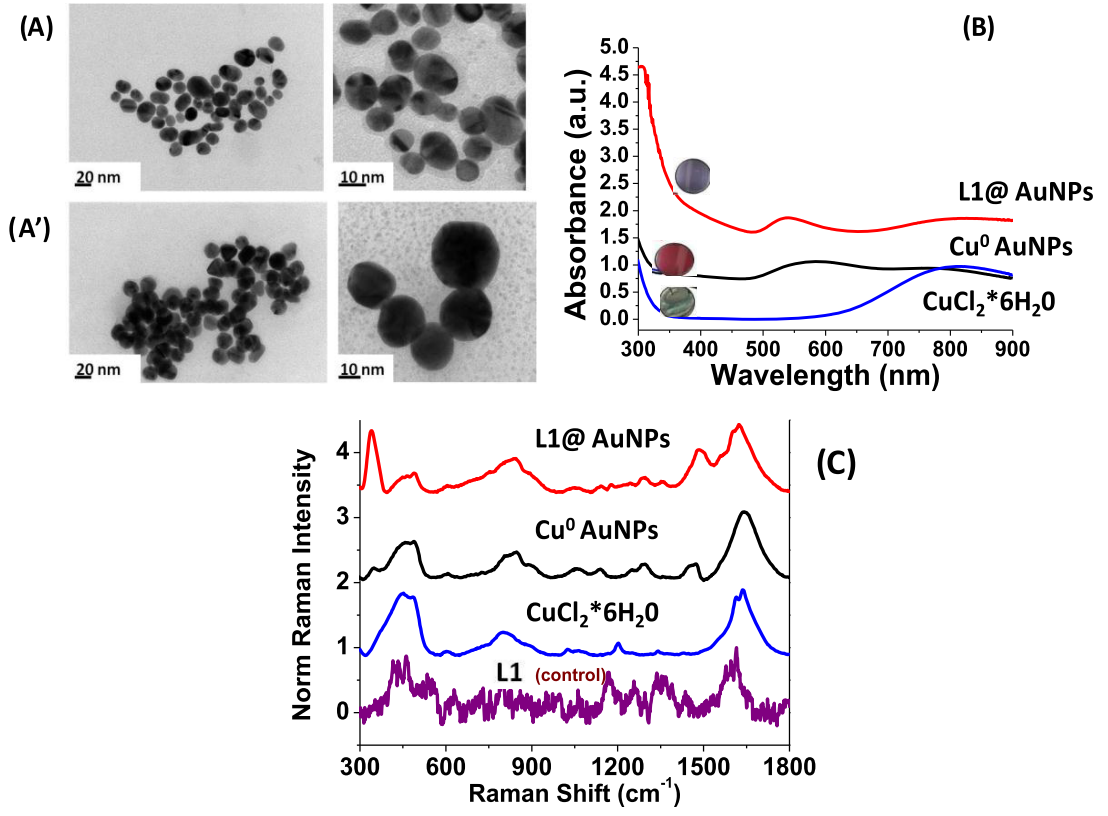

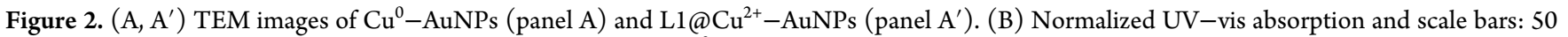
and $20 \mathrm{~nm}$ for $\mathrm{Cu}-\mathrm{AuNPs}$ and $0.2 \mu \mathrm{m}$ and $100 \mathrm{~nm}$ for $\mathrm{L} 1 @ \mathrm{Cu}^{2+}-\mathrm{AuNPs}$ and $\mathrm{CuCl}_{2} \cdot 6 \mathrm{H}_{2} \mathrm{O}$ as control. (C) Raman spectra of $\mathrm{Cu}-\mathrm{AuNPs}$ and $\mathrm{L} 1 @ \mathrm{Cu}^{2+}-\mathrm{AuNPs}$ products compared to free $\mathrm{L} 1$ and $\mathrm{CuCl}_{2} \cdot 6 \mathrm{H}_{2} \mathrm{O}$ as control. Raman spectra. Experimental conditions: $\lambda_{\text {exc }}=785 \mathrm{~nm}$; laser power $20 \mathrm{~mW}$; accumulation time $180 \mathrm{~s}$.

followed by a conformational change to brush mode. ${ }^{15,17}$ The final reduction by $\mathrm{NaBH}_{4}$ completed the grow process to form L1@ $\mathrm{Cu}^{2+}-$ AuNPs. All products of our synthetic procedure were characterized by UV-vis absorption spectroscopy, transmission electron microscopy (TEM), and Raman spectroscopy.

2.3. Comparative Physicochemical Characterization of $\mathrm{Cu}^{0}-\mathrm{AuNPs}$ and $\mathrm{L} 1 @ \mathrm{Cu}^{2+}-$ AuNPs. TEM images of $\mathrm{Cu}^{0}-\mathrm{AuNPs}$ showed a well dispersion of the nanoparticles with an average size of $20 \pm 1 \mathrm{~nm}$ (Figure 2A overpanel). Different nanostructures were obtained with $\mathrm{L} 1 @ \mathrm{Cu}^{2+}-$ AuNPs: they exhibited a nanocapsule-like shape embedded in a shell of PEG, in which metal nanoparticles showed a diameter of around $28 \pm 2 \mathrm{~nm}$ (Figure $2 \mathrm{~A}$ underpanel). The synthesis of $\mathrm{Au} / \mathrm{Cu}$ alloy nanoparticles using biocompatible liquid polymer ${ }^{22}$ and the fabrication of snowflakes nanoparticles by catalytic $\mathrm{CO}$ oxidation ${ }^{11}$ have been already reported. Anyway, a study about the grafting of L1 ligands onto $\mathrm{Cu}^{0}-\mathrm{AuNPs}$ has not been reported. When L1 ligands were added to the $\mathrm{Cu}^{2+}-\mathrm{AuCl}$ solution, the picolinate amino group was initially electrostatically bound to $\mathrm{Au}-\mathrm{Cu}$ clusters, followed by a conformational change of the ligand L1 that chelated $\mathrm{Cu}^{2+}$ ions completely and successively embedded in the dicarboxylic PEG in a mushroom conformation. ${ }^{15}$

Figure $2 \mathrm{~B}$ black line reports the absorption spectra of hybrid $\mathrm{Cu}^{0}-\mathrm{AuNPs}$, all characterized by a surface plasmon band in the range of $560 \mathrm{~nm}$, together with a small peak at $775 \mathrm{~nm}$. The slow shift of the band position depended on the ratio of the gold salt and the capping materials during the reaction processes. ${ }^{30,31}$ This peak could be generally ascribed to collective oscillation, known as the surface plasmon oscillation of the metal electrons in the conduction band, due to interaction of electrons with light of a certain wavelength. PEG could be used as a stabilizing polymer for AuNPs because the dispersed solutions could be obtained due to the formation of coordination bands between $\mathrm{Au}$ and $\mathrm{Cu}$ ions with the carboxylic group. The chelation effect even better dispersed $\mathrm{Au}$ and $\mathrm{Cu}$ ions, which were reduced to form single $\mathrm{Cu}^{0}-$ AuNPs of relatively uniform size. Figure $2 \mathrm{~B}$ red line displays a $\mathrm{UV}-$ vis an absorption spectrum of $\mathrm{L} 1 @ \mathrm{Cu}^{2+}-\mathrm{Au}$ NPs. Compared with $\mathrm{Cu}^{0}-$ AuNPs spectrum, a blue shift of the plasmon peak from 560 to $535 \mathrm{~nm}$ and a red shift of the peak at $775-810 \mathrm{~nm}$ could be observed. The latter was associated to $\pi-\pi^{*}$ electronic transitions due to interactions between the L1 ring and $\mathrm{CuAuCl}_{2}$ ions and gave a clear evidence of the complex formation with a change of color of the colloidal solution from pink red $\left(\mathrm{Cu}^{0}-\mathrm{AuNPs}\right)$ to bright violet ( $\mathrm{L} 1 @$ $\left.\mathrm{Cu}^{2+}-\mathrm{Au} \mathrm{NPs}\right)$.

The NP sizes were confirmed by dynamic light scattering (DLS) measurements (Table 1). C-Potential measurements

Table 1. $\zeta$-Potential and Hydrodynamic Diameter of $\mathrm{Cu}^{0}-$ AuNPs and L1@C $\mathrm{Cu}^{2+}-$ AuNPs

\begin{tabular}{lccc} 
synthetic product & $\begin{array}{c}\zeta \text {-potential } \\
(\mathrm{mV})\end{array}$ & $\begin{array}{c}\text { hydrodynamic diameter } \\
(\mathrm{nm})\end{array}$ & PdI \\
$\mathrm{Cu}^{0}-$ AuNPs & $-25 \pm 3$ & $20 \pm 2$ & 0.3 \\
$\mathrm{~L} 1 @ \mathrm{Cu}^{2+}-$ AuNPs & $-20 \pm 2$ & $28 \pm 2$ & 0.3 \\
\hline
\end{tabular}

showed that $\mathrm{Cu}^{0}-\mathrm{AuNPs}$ and $\mathrm{L} 1 @ \mathrm{Cu}^{2+}-\mathrm{AuNPs}$ were stable colloids at physiological $\mathrm{pH}(\zeta$-potential $=-25 \pm 3$ and $-20 \pm$ $2 \mathrm{mV}$ with a PdI equal to 0.3 ) (Table 1 ). This stability was enhanced by the presence of the PEG layer around nanoparticles. $^{25}$

Raman spectra of $\mathrm{Cu}^{0}$-AuNPs exhibited many bands in the region $500-2000 \mathrm{~cm}^{-1}$ (Figure 3C black line). The wide band observed around $1600 \mathrm{~cm}^{-1}$ on the Raman spectra was assigned to the water. The strong band at $1712 \mathrm{~cm}^{-1}$ was assigned to $\mathrm{C}=\mathrm{O}$ carbonyl stretching of PEG diacid. The intense doublet at $720-760 \mathrm{~cm}^{-1}$ was due to the $\mathrm{C}-\mathrm{H}$ plane deformation and a strong peak at $1439 \mathrm{~cm}^{-1}$ was assigned to $\nu \mathrm{C}-\mathrm{C}$ stretching. These bands were due to the variation of the steric conformation of the PEG diacide and became more 


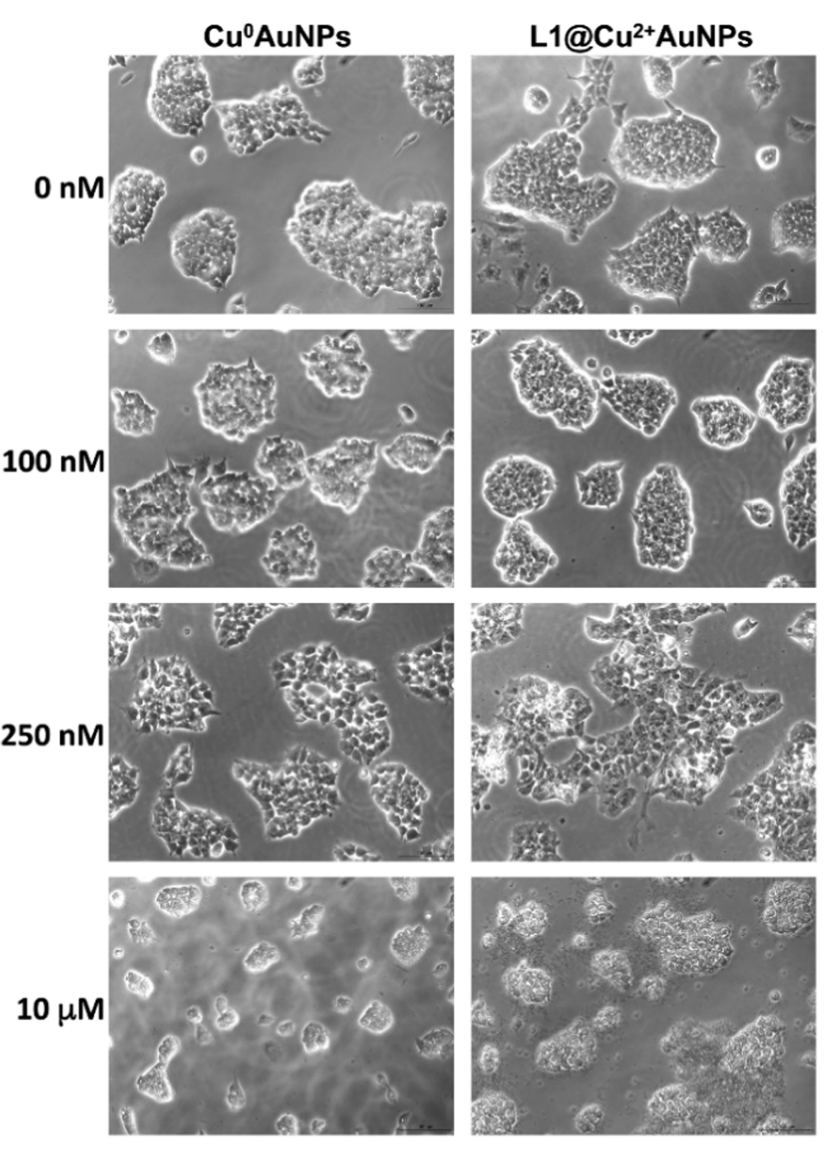

Figure 3. Cytotoxicity of ES cells incubated with different concentrations of $\mathrm{Cu}^{0}-\mathrm{AuNPs}$ or $\mathrm{L} 1 @ \mathrm{Cu}^{2}-\mathrm{AuNPs}$ nanoparticles $(0-10 \mu \mathrm{M})$ for $24 \mathrm{~h}$. Bar $=50 \mu \mathrm{m}$.

prominent upon complexation with $\mathrm{Cu}-\mathrm{AuCl}_{2}$, as previously described. ${ }^{16,20}$ As matter of fact, when $\mathrm{C}=\mathrm{O}$ and hydroxyl groups of PEG diacide interacted with a metal, the sterical conformation became more tilted with respect to the planar one. Focusing on the spectral range $200-500 \mathrm{~cm}^{-1}$ (Figure $2 \mathrm{C}$ ), we can observe several spectral changes, which confirmed a chemical modification of $\mathrm{Cu}$ after complexation with gold ions and PEG diacide molecules. One of the Raman fingerprint of the $\mathrm{Cu}-\mathrm{PEG}-\mathrm{AuNP}$ s was the presence of a band around $263 \mathrm{~cm}^{-1}$, and a double peak at $235-285 \mathrm{~cm}^{-1}$ was observed. These bands could be assigned to the gold chloride stretches, $\nu(\mathrm{Au}-\mathrm{Cl})$, and $\delta(\mathrm{O}-\mathrm{Au}-\mathrm{O})$ and $\delta(\mathrm{Cu}-\mathrm{Au}-\mathrm{O})$ are a clear evidence of the formation of a complex between $\mathrm{AuCl}_{2}{ }^{-}$and $\mathrm{Cu}$ and PEG diacide in the solution. The peak at $430 \mathrm{~cm}^{-1}$ was due to the vibrations $\delta(\mathrm{OH} \cdots \mathrm{O}), \nu(\mathrm{OH} \cdots \mathrm{O})$ of the PEG, as previously described. ${ }^{15,16}$ The bands in the region $3000 \mathrm{~cm}^{-1}$ could be assigned to the aromatic $\mathrm{C}-\mathrm{H}$ stretching (Figure 2C). A broad band composed of some peaks appeared in the spectral range 2850-2930 due to the symmetric $\mathrm{CH}_{2}-\mathrm{CH}_{3}$ stretch vibration of PEG diacide molecules, confirming the main role of the polymer in the synthesis of the nanoparticle. The steric arrangement of L1 ligand during the synthesis process of PEGylated copper-gold nanoparticles was confirmed by Raman spectroscopic analysis (Figure 2C).

Raman spectra of free L1@ $\mathrm{Cu}^{2+}-$ AuNPs in water showed SERS effect in the range $300-1800 \mathrm{~cm}^{-1}$. The spectral modifications were evidence of the steric conformational change of the L1 after grafting on the copper-gold nanoparticles. One of the Raman fingerprints of the L1@
$\mathrm{Cu}^{2+}$-AuNPs was the presence of a band around $340 \mathrm{~cm}^{-1}$ due to the copper(II) peroxide complex, where L1 chelates $\mathrm{Cu}^{2+}$. The common peak at $450 \mathrm{~cm}^{-1}$ was due to the vibrations $\delta(\mathrm{OH} \cdots \mathrm{O}), \nu(\mathrm{OH} \cdots \mathrm{O})$ of the PEG as previously described. $^{15,16}$ On the basis of the spectrochemical and previously theoretical findings, we assumed that $\mathrm{Au}^{3+}$ ions promoted the deprotonation of the $\mathrm{L} 1$ amino group. These bands were due to variation of the steric conformation of the $\mathrm{L} 1$ and became more prominent upon electrostatic interaction with gold cluster and then chelation with $\mathrm{Cu}^{2+}$.

2.4. Cytotoxicity of $\mathrm{Cu}^{0}-\mathrm{AuNPs}$ and $\mathrm{L} 1 @ \mathrm{Cu}^{2+}$ AuNPs. Murine ES cells and neural-derived ES cells were exposed to $\mathrm{Cu}^{0}-\mathrm{AuNPs}$ and $\mathrm{L} 1 @ \mathrm{Cu}^{2+}-\mathrm{AuNPs}$ nanoparticles at different concentrations (0-1000 nM) for $24 \mathrm{~h}$ (Figure 3), and cytotoxicity was analyzed by live-dead staining, and LC50 was calculated. At maximum used concentration $(10 \mu \mathrm{M})$, both kinds of nanoparticles determined the death of almost all the cells. They resulted not cytotoxic for concentrations up to $100 \mathrm{nM}$, suggesting a fair good biocompatibility at this concentration. However, the NPs were found to display significant cytotoxicity still at the concentration of $250 \mathrm{nM}$. The nanoparticles showed concentration-dependent cytotoxicity in both cells: the neural-derived ES cells were more sensitive toward the toxicity of both particles than the undifferentiated ES cells. The results highlight the difference of cytotoxicity between nanoparticles used and differential sensitivity of cells to $\mathrm{Cu}^{0}-\mathrm{AuNPs}$ or $\mathrm{L} 1 @ \mathrm{Cu}^{2}-\mathrm{AuNPs}$. However, the toxic response varied depending on the type of cell exposed due to differential sensitivity.

The results obtained on ES cells were used to identify the range of NPs concentrations to test the cytotoxicity on neuralderived ES cells. These cells were exposed to the same concentration of $\mathrm{Cu}^{0}-\mathrm{AuNPs}$ and $\mathrm{L} 1 @ \mathrm{Cu}^{2+}-\mathrm{AuNPs}$, i.e., 0100-250-1000 nM, for $24 \mathrm{~h}$. The $50 \%$ of lethal dose for both NPs, reported in Table 2, was determined using trypan blue dye exclusion.

Table 2. LD50 of Neural-Derived ES Cells after $24 \mathrm{~h}$ of Treatment with $\mathrm{Cu}^{0}-\mathrm{AuNPs}$ or L1@ $\mathrm{Cu}^{2+}-$ AuNPs Nanoparticles

\begin{tabular}{lcc} 
& $\mathrm{LD} 50 \%(\mathrm{nM})$ & $\mathrm{LD} 50 \%(\mu \mathrm{g} / \mathrm{mL})$ \\
$\mathrm{Cu}^{0}-\mathrm{AuNPs}$ & 600 & 0.16 \\
$\mathrm{~L} 1 @ \mathrm{Cu}^{2+}-$ AuNPs & 950 & 0.25 \\
\hline
\end{tabular}

On neural-derived ES cells, the $\mathrm{Cu}^{0}-\mathrm{AuNPs}$ were more toxic, with LD50 value of $600 \mathrm{nM}$, than the L1@ $\mathrm{Cu}^{2+}-\mathrm{AuNPs}$ nanoparticles, with LD50 value of $950 \mathrm{nM}$. Light microscopy analysis characterized the effect of different concentrations of NPs on neural-derived ES cells morphology. Even at $100 \mathrm{nM}$, both NPs preserved the cell viability and morphology, with quite equal toxicity profile observed for both NPs; at $250 \mathrm{nM}$, neural-derived ES cells treated with $\mathrm{L} 1 @ \mathrm{Cu}^{2+}-\mathrm{Au}$ NPs exhibited more neurite reduction than those treated with $\mathrm{Cu}^{0}$-AuNPs. At $1000 \mathrm{nM}$ of both NPs, the cells appeared to refract the light, suggesting a typical apoptotic phenotype (Figure 4).

2.5. Determination of Cellular Uptake of NPs by Confocal Microscopy. The neural-derived ES cells were plated on a gelatin-coated microscope slide and left to adhere

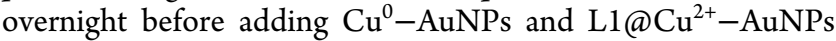
labeled with the fluorophore at $200 \mathrm{nM}$, a concentration well below the LD50 for both kinds of NPs. As shown in Figure 5, 


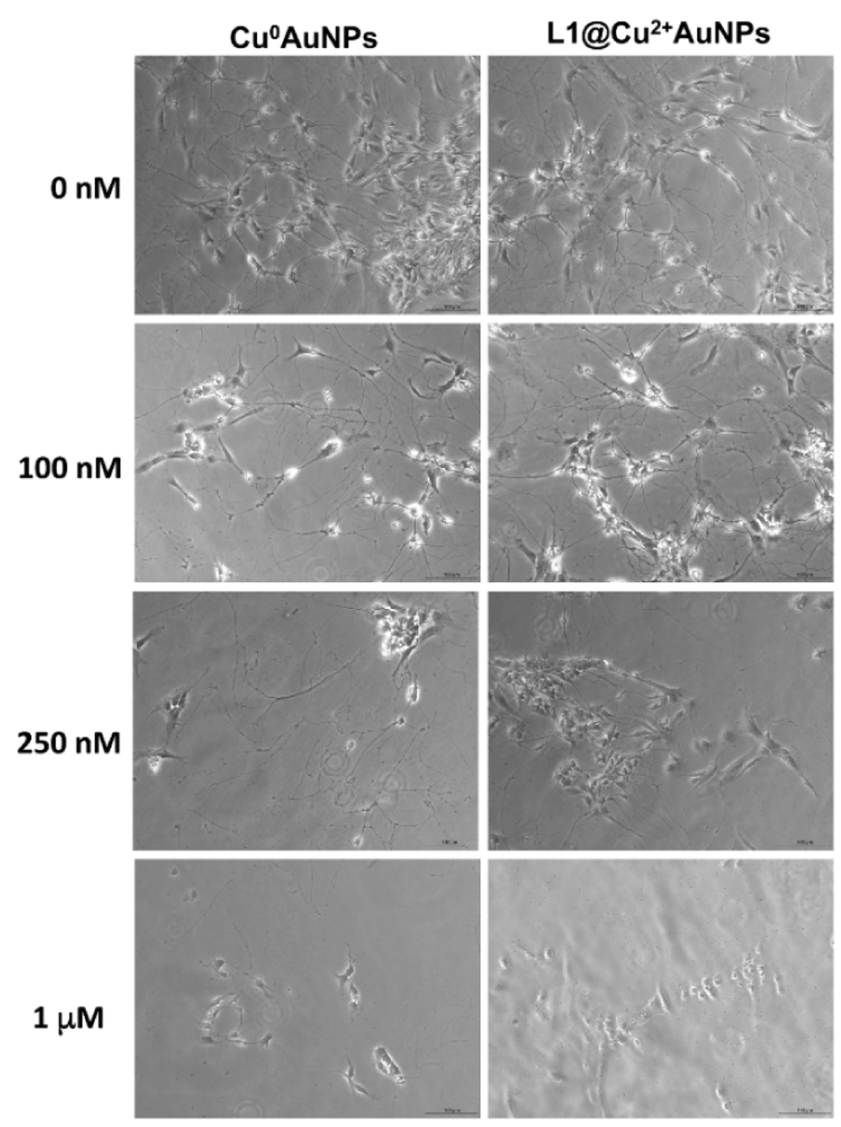

Figure 4. Cytotoxicity of neural-derived ES cells incubated with different concentrations of $\mathrm{Cu}^{0}-\mathrm{AuNPs}$ or $\mathrm{L} 1 @ \mathrm{Cu}^{2+}-\mathrm{AuNPs}$ nanoparticles $(0-100-250-1000 \mathrm{nM})$ for $24 \mathrm{~h}$. Bar $=50 \mu \mathrm{m}$.

both NPs synthetized were internalized into neural-derived ES cells but with some qualitative differences. Confocal images showed $\mathrm{Cu}^{0}-\mathrm{AuNPs}$ internalized more than $\mathrm{L} 1 @ \mathrm{Cu}^{2+}-$ AuNPs. Moreover, even if slightly larger, the $\mathrm{Cu}^{0}-$ AuNPs were internalized also inside the nucleus. This capability may be caused by a more efficient interaction with mammalian cell membranes.

Confocal images confirmed that NPs were mainly located within the cell and not adhered to the cell surface: the fluorescent signal of $\mathrm{Cu}^{0}-\mathrm{AuNPs}$ was predominantly observed in the cytoplasm and also in the nuclei; on the contrary, the fluorescent signal of L1@ $\mathrm{Cu}^{2+}-\mathrm{AuNPs}$ was prevalently present in the cytoplasm (Figure 5).

From data collected in biological experiments, a typeselective difference in NP toxicity was observed. A possible reason for the difference in uptake and distribution inside the neural-derived ES cells could be the different surface chemistry of two NPs synthetized, which could improve the endocytosis mechanisms up to the nucleus in case of $\mathrm{Cu}^{0}-\mathrm{AuNPs}$. Experimental results indicated that the differences between $\mathrm{Cu}^{0}-\mathrm{AuNPs}$ and $\mathrm{L} 1 @ \mathrm{Cu}^{2+}-\mathrm{AuNPs}$ nanoparticles as well as the target cell type were critical determinants of intracellular responses and degree of cytotoxicity. At this stage, it was not possible to completely highlight the mechanism underlying the differential toxicity. The evidence emerging from the experimental results was that apoptosis is the predominant death pathway for moderate concentrations of NPs in the solution, whereas necrosis was the predominant pathway for high concentrations of NPs, according to the data reported in literature. ${ }^{32,33}$ Large amount of $\mathrm{Cu}$-based nanoparticles, once internalized in neurons, caused severe alterations of cell morphology up to membrane disruption, according to the images reported in Figure 4 from concentrations of $100 \mathrm{nM}$ onward. Light concentration of copper NPs inside neuron cells caused apoptosis as a consequence of oxidative stress induced by reactive oxygen species associated to metallic nanoparticles.

2.6. Optical Imaging of Cells. Internalization of cells of the synthesized colloids ( $\mathrm{Cu}^{0} \mathrm{AuNPs}$ and L1@ $\mathrm{Cu}^{2+} \mathrm{AuNPs}$ ) was carried out with a confocal microscope (Horiba Scientifics) under bright- and dark-field illumination. The images reported in Figures S3 and S4 are from the treated ES neuronal cells in different areas, the same sample region was seen in bright-field (a) and dark-field conditions (b). The darkfield image showed a high density of bright, small scattering centers dispersed all over the glass slide. The density of these bright spots clearly showed an effect of concentration addiction when the colloids were incubated. It appears that the colloids had a tendency to accumulate inside the cells in the experimental conditions previously described. ${ }^{17}$

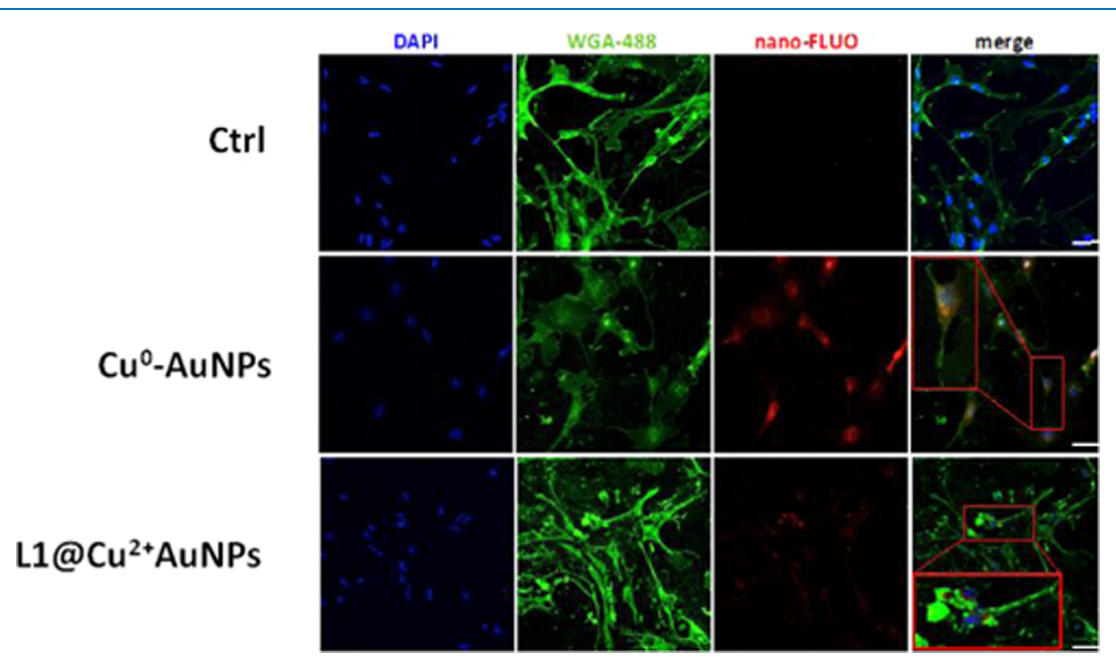

Figure 5. Confocal fluorescence images of neural-derived ES cells incubated with $\mathrm{Cu}^{0}-\mathrm{AuNPs}$ or L1@Cu${ }^{2+}-\mathrm{AuNPs}(200 \mu \mathrm{g} / \mathrm{mL})$ for $24 \mathrm{~h}$. Bar $=$ $50 \mu \mathrm{m}$. 
Scheme 4. Synthesis of L1 (cb-te1pa-Et $\left.p \mathrm{PhNH}_{2}\right): \mathrm{L1}^{a}$<smiles>COC(=O)c1cccc(CN2CCCN(CCCl)CC2)n1</smiles>

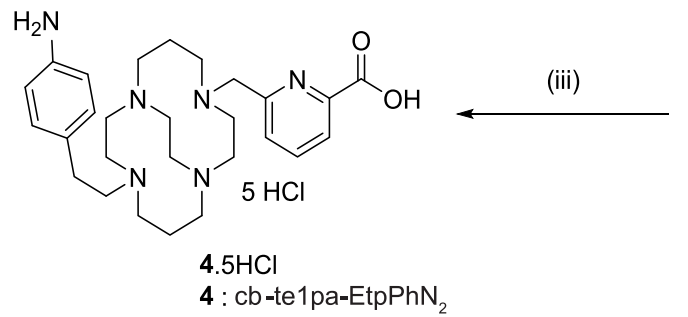

(i)
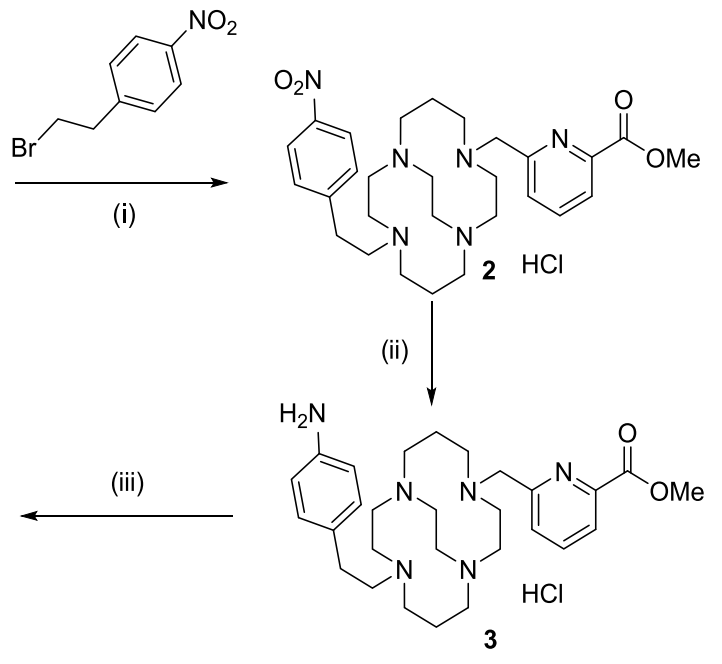

${ }^{a}(\mathrm{i}) \mathrm{K}_{2} \mathrm{CO}_{3}, \mathrm{CH}_{3} \mathrm{CN}, 12 \mathrm{~h}$, reflux, 85\%; (ii) tin chloride $\mathrm{MeOH} / \mathrm{HCl}$ aq $12 \mathrm{M}$, room temperature, $12 \mathrm{~h}, 83 \%$; and (iii) hydrochloric acid $6 \mathrm{M}$, reflux, $12 \mathrm{~h}$, quant.

\section{MATERIALS AND METHODS}

All chemicals were of reagent grade or higher and used as received unless otherwise specified. Tetrachloroauric acid $\left(\mathrm{HAuCl}_{4} \cdot \mathrm{H}_{2} \mathrm{O}\right), \mathrm{CuCl}_{2} \cdot 6 \mathrm{H}_{2} \mathrm{O}$, sodium borohydride $\left(\mathrm{NaBH}_{4}\right)$, poly(ethylene glycol)-600 (PEG 600), and phosphate buffered saline (PBS, $0.1 \mathrm{M}, \mathrm{pH}$ 7.0, $\mathrm{pH}$ 4.0, $\mathrm{pH}$ 9.0) were purchased from Organics and from Aldrich Chemical Co.

3.1. L1 Synthesis. L1 synthesis was based on previous work that is summarized in Scheme 4. Briefly, starting from compound 1, the methyl ester of telpa, the addition of 4nitrophenylethyl bromide led to compound 2 with $85 \%$ yield. The specific reduction of the nitrophenyl was managed with tin chloride with $83 \%$ yield and produced compound 3. A final hydrolysis removed the ester function and generated the bifunctional cb-telpa-Et $p \mathrm{PhNH}_{2}$ (compound 4). In the following sections, the final product cb-telpa-Et $p \mathrm{PhNH}_{2}$ will be simply called $\mathrm{L}$.

NMR was performed on Bruker 300 advance spectrometers. ${ }^{2} \mathrm{D}$ NMR ${ }^{1} \mathrm{H}-{ }^{1} \mathrm{H}$ homonuclear, ${ }^{1} \mathrm{H}-{ }^{13} \mathrm{C}$ heteronuclear correlations, and homonuclear decoupling experiments were used for assignment of the ${ }^{1} \mathrm{H}$ and ${ }^{13} \mathrm{C}$ signals. The $\delta$ scales are relative to tetramethylsilane $\left({ }^{1} \mathrm{H},{ }^{13} \mathrm{C}\right)$. The signals are indicated as follows: chemical shift, intensity, multiplicity (s, singlet; br s, broad singlet; d, doublet; $t$, triplet; m, multiplet; $q$, quartet), coupling constants $J$ in hertz $(\mathrm{Hz})$. The high resolution mass spectrometry (HR-MS) analyses were performed at the Institute of Analytic and Organic Chemistry, ICOA in Orleans. In details, compound L1 was synthetized by a three-step procedure, which is reported in the following section. Results of HR-MS are reported for each step in the Supporting Information.

3.1.1. Step (i): trans-Di-N-functionalization of CrossBridged Monomethylpicolinate Cyclam (Compound 1) Yielding Compound 2. 4-Nitrophenylethyl bromide (0.968 g, $4.20 \mathrm{mmol})$ and potassium carbonate $(0.872 \mathrm{~g}, 6.31 \mathrm{mmol})$ were add to a solution of $1(0.865,2.10 \mathrm{mmol})$ in $200 \mathrm{~mL}$ of distilled acetonitrile. The mixture was refluxed overnight. After the evaporation of the solvent, the crude product was purified by column chromatography in silica gel $\left(\mathrm{CHCl}_{3} / \mathrm{MeOH} 8: 2\right)$ to yield compound 2 as a yellow oil (1.000 g, 85\%).

3.1.2. Step (ii): Reduction of Compound 2 Yielding Compound 3. Tin chloride $(1.810 \mathrm{~g}, 9.55 \mathrm{mmol})$ and compound $2(0.500 \mathrm{~g}, 0.95 \mathrm{mmol})$ were add to a $40 \mathrm{~mL}$ solution 1:9 of $\mathrm{MeOH} / \mathrm{HCl}$ aq $12 \mathrm{M}$. The mixture was stirred at room temperature overnight and then excess $\mathrm{HCl}$ was neutralized using potassium carbonate. The desired compound 3 was obtained by extraction with chloroform at $\mathrm{pH} 14$ as yellow oil (420 mg, 83\%).

3.1.3. Step (iii): Hydrolysis of Compound 3 Yielding Compound 4 (L1). Hydrochloric acid (10 mL, $6 \mathrm{M})$ was slowly added to compound $3(0.200 \mathrm{~g}, 0.38 \mathrm{mmol})$ and the mixture was refluxed overnight. After cooling to room temperature, the solvent was evaporated to yield compound 4 (L1) as an off-white solid in quantitative yield.

3.2. Synthesis of $\mathrm{Cu}^{0}$-AuNPs. Twenty milliliters of $0.0001 \mathrm{M}$ aqueous $\mathrm{HAuCl}_{4}$ was mixed with $5 \mathrm{~mL}$ of $\mathrm{CuCl}_{2}$. $6 \mathrm{H}_{2} 0$ solution $\left(6.10 \times 10^{-5} \mathrm{M}\right.$ in water $)$ at room temperature for $1 \mathrm{~h}$ under magnetic stirring to form a $\mathrm{Au}-\mathrm{Cu}$ blend. Then, $250 \mu \mathrm{L}$ of poly(ethylene glycol) 600 diacid (PEG) was mixed to the blend solution under stirring for $2 \mathrm{~h}$. After this time, 3.6 $\mathrm{mL}$ of $\mathrm{NaBH}_{4}(0.01 \mathrm{M})$ was added dropwise, followed by rapid stirring and kept without agitation for $2 \mathrm{~h}$. The color of the dispersion indeed instantly changed from green-yellow to pinkred when sodium borohydride was added to a solution of copper-gold precursor in the presence of the PEG diacid polymer, with a complete reduction of metal ions confirming the formation of hybrid nanoparticles in the solution. The asprepared $\mathrm{Cu}^{0}-$ AuNPs solution was purified by centrifugation and dialysis to remove excess of not-conjugated dicarboxylic PEG. ${ }^{14}$

3.3. Synthesis of $\mathrm{L} 1 @ \mathrm{Cu}^{2+}-\mathrm{AuNPs}$. The synthesis of L1@ $\mathrm{Cu}^{2+}-\mathrm{AuNPs}$ colloids is described here. Twenty milliliters of $\mathrm{HAuCl}_{4}$ aqueous solution $\left(2.5 \times 10^{-4} \mathrm{M}\right.$ in water $)$ was added to $\mathrm{CuCl}_{2}$ solution $\left(5 \mathrm{~mL}, 6.10 \times 10^{-5} \mathrm{M}\right.$ in water $)$ under stirring for $1 \mathrm{~h}$. After this time, $5 \mathrm{~mL}$ of $\mathrm{L} 1\left(2.3 \times 10^{-4}\right.$ $\mathrm{M}$ in water) was mixed to this hybrid blend solution during 1 $h$, and the mixture was stirred at room temperature. At the end 
of this reaction, $250 \mu \mathrm{L}$ of dicarboxylic PEG was mixed to the solution and stirred for $1 \mathrm{~h}$. Finally, $3.6 \mathrm{~mL}$ of aqueous $0.01 \mathrm{M}$ $\mathrm{NaBH}_{4}$ was added at once until stabilization and reduction to hybrid nanoparticles. The "as-prepared" L1@ $\mathrm{Cu}^{2+}-\mathrm{AuNPs}$ solution was centrifuged at $5000 \mathrm{rpm}$ for $20 \mathrm{~min}$ for three times and then the supernatant was discarded. This was repeated twice to remove excess of not-conjugated reagents. L1@ $\mathrm{Cu}^{2+}-$ AuNPs were stored at $8{ }^{\circ} \mathrm{C}$ and characterized by UV-vis spectroscopy, transmission electron microscopy, and Raman spectroscopy.

3.4. Physicochemical Characterization. All the measurements were performed in triplicate to validate the reproducibility of the synthetic and analytical procedures. ${ }^{15,16}$

3.4.1. UV-Vis Measurements. Absorption spectra were recorded using a PerkinElmer Lambda UV/Vis 950 spectrophotometer in plastic cuvettes with an optical path of $10 \mathrm{~mm}$. The wavelength range was $200-900 \mathrm{~nm}$.

3.4.2. Transmission Electron Microscopy (TEM). Size and morphology of NPs were characterized by transmission electron microscopy (TEM) (JEM-1011 TEM, Jeol, Inc., Peabody, MA) using a Morada CCD camera at an accelerating voltage of $100 \mathrm{kV}$.

3.4.3. Raman Spectroscopy. The Raman experiments have been performed on an Xplora spectrometer (Horiba Scientifics-France). ${ }^{15,16}$

3.4.5. Optical Imaging. The optical images of the cells were carried out as previously reported. ${ }^{17}$

3.4.6. Dynamic Light Scattering (DLS). The size measurements were performed using a Zetasizer Nano ZS (Malvern Instruments, Malvern, U.K.) equipped with a $\mathrm{He}-\mathrm{Ne}$ laser $\left(633 \mathrm{~nm}\right.$, fixed scattering angle of $\left.173^{\circ}\right)$ at room temperature.

3.4.7. $\zeta$-Potential Measurements. The $\zeta$-potential of AuNPs dispersed in water was measured using the electrophoretic mode of a Zetasizer Nano ZS (Malvern Instruments Ltd, U.K.).

3.5. ES Cells Culture Conditions. Embryonic stem cells (ESCs) can be used as a model system in basic research, drug discovery, biomedical applications, and nanotechnology because they combine the potential of unlimited self-renewal with the ability to differentiate into a wide range of tissuespecific cells. The present study was designed to determine if the nanoparticles $\mathrm{Cu}^{0}-\mathrm{AuNPs}$ and $\mathrm{L} 1 @ \mathrm{Cu}^{2+}-\mathrm{AuNPs}$ could have toxic effects on undifferentiated and neural differentiated ES cells. Wild-type mouse AK7 ES cells were maintained in an undifferentiated state by culture on a monolayer of mitomycin$\mathrm{C}$-inactivated fibroblast in the presence of leukemia-inhibiting factor as previously described. ${ }^{18}$ At $24 \mathrm{~h}$ before treatment, the cells were seeded on gelatin-coated plates at a density of $4 \times$ $10^{4}$ cells $/ \mathrm{cm}^{2}$ to allow attachment.

3.5.1. In Vitro Neurons Differentiation. Neural progenies can be generated from ESC with high standards of accuracy and reliability. To induce neural differentiation, essentially according to Fico et al., ${ }^{18}$ AK7 ES cells at $48 \mathrm{~h}$ before inducing differentiation were seeded on gelatin-coated plates. At day 0 , the ES cells were dissociated in a single-cell suspension and 1500 cells $/ \mathrm{cm}^{2}$ were plated on gelatin-coated plates. The cells were maintained in differentiation medium until day 7 when neural precursors cells were detached using 0.05\% trypsin/ ethylenediaminetetraacetic acid solution and frozen in $90 \%$ FBS $+10 \%$ dimethyl sulfoxide. Frozen cells were thawed and immediately plated at 66000 cells $/ \mathrm{cm}^{2}$ in Matrigel-coated plates. The medium was changed every day until day 13 .
3.6. Cell Death Assay. The lethal dose 50 (LD50) is the amount of a chemical, calculated as the concentration of chemicals that produces death in $50 \%$ of a cellular population.

To determine the lethal dose 50 (LD50) of the nanoparticles $\mathrm{Cu}^{0}-\mathrm{AuNPs}$ and $\mathrm{L} 1 @ \mathrm{Cu}^{2+}-$ AuNPs on undifferentiated ES and neural-derived ES cells, these cells were seeded, respectively, on gelatin-coated or Matrigel-coated plates. The cells were untreated or treated with different concentrations $(0-1000 \mathrm{nM})$ of $\mathrm{Cu}^{0}-\mathrm{AuNPs}$ or $\mathrm{L} 1 @ \mathrm{Cu}^{2+}-\mathrm{AuNPs}$ nanoparticles for $24 \mathrm{~h}$, then collected, counted, and analyzed for their ability to incorporate the cell-permeable dye trypan blue. Concomitantly, other cells, untreated or treated in the same way, were visualized by phase-contrast microscopy using the DMI6000B inverted fully automated microscope with DFC 420 RGB camera (Leica Microsystems, Wetzelar, Germany). Leica LAS V5.4 software was used for image acquisition/ elaboration (contrast $/ \gamma$ adjusting).

3.7. Immunofluorescence Analysis. For nanoparticles internalization experiments, neural-differentiated ESCs were seeded in six-well plates and cultured for $24 \mathrm{~h} . \mathrm{Cu}^{0}-\mathrm{AuNPs}$ or L1@ $\mathrm{Cu}^{2+}-\mathrm{AuNPs}$ conjugated with Alexa-Fluor-594, suspended in culture medium at $200 \mathrm{nM}$, were incubated with cells for $24 \mathrm{~h}$. After the incubation, the cells were rinsed twice in PBS to remove the noninternalized nanoparticles, fixed in $4 \%$ paraformaldehyde for $30 \mathrm{~min}$, and washed in PBS $1 \times$. After washing, the cells were incubated with WGA-488 (Invitrogen) as membrane marker following manufacturer's instructions. Nuclei were counterstained with Hoechst 33342 (Invitrogen). Fluorescent labeling was visualized using the inverted fully automated confocal Nikon AR-1 microscope. The NIS elements software was used for image acquisition/elaboration.

\section{CONCLUSIONS}

Designing hybrid functional nanoparticles for biomedical applications is still a current challenge in terms of performances, stability, and safety in biological media. In particular, if gold nanoparticles are known for their high in vivo inertness and their use in several applications, including their photophysical properties, the use of copper(II) into the hybrid nanoparticles is still not a trivial task. Once copper is inside the metallic aggregates, it is usual to obtain unstable and/or cytotoxic effects coming from the hybrid nanostructure.

The success of this study was then to provide the design, the synthesis, and the characterization of new potential nanocomplexes based on the incorporation of chelated copper(II) in gold nanoparticles. Highly thermodynamically stable and kinetically and electrochemically inert copper(II) chelates have been used based on a proven cyclam cross-bridged ligand, the cb-telpa chelator. Its insertion was facilitated by the presence of aniline moiety, a carboxylic function, and its overall charge and proved all along the nanomaterials characterization. In conclusion, from the results obtained, there is evidence of a type-selective difference in NP toxicity in favor of $\mathrm{L} 1 @ \mathrm{Cu}^{2}-$ AuNPs. Possible reason to explain nanoparticle-specific uptake and distribution inside the neural-derived ES cells may be attributed to the peculiar features of $\mathrm{Cu}^{0}-\mathrm{AuNPs}$ or L1@ $\mathrm{Cu}^{2}-\mathrm{AuNPs}$ nanoparticles. Our results indicated that the differences between $\mathrm{Cu}^{0}-\mathrm{AuNPs}$ or $\mathrm{L} 1 @ \mathrm{Cu}^{2}-\mathrm{AuNPs}$ nanoparticles as well as the target cell type are critical determinants of intracellular responses and degree of cytotoxicity. These results allow us to hypothesize that the apoptosis is the predominant death pathway for moderate concentrations of 
NPs in the solution, whereas necrosis is the predominant pathway for high concentrations of NPs.

Toxicity comparison with respect to previously reported results in literature is not straightforward because ES neuron cells are not very commonly diffused in many laboratories; nevertheless, the synthetized Cu-based NPs showed LD levels of the same order of those mentioned in critical review study, recently published. ${ }^{34}$

\section{ASSOCIATED CONTENT}

\section{S Supporting Information}

The Supporting Information is available free of charge on the ACS Publications website at DOI: 10.1021/acsomega.8b03266.

UV-vis absorption of $\mathrm{HAuCl}_{4} \cdot 6 \mathrm{H}_{2} \mathrm{O}$ (black line), $\mathrm{CuCl}_{2} \cdot 6 \mathrm{H}_{2} \mathrm{O}$ (red line); and $\mathrm{Au}-\mathrm{Cu}$ blend (blue line) (Figure S1); UV-vis spectra of each solutions: $\mathrm{HAuCl}_{4}$, $\mathrm{CuCl}_{2}$, and $\mathrm{HAuCl}_{4}-\mathrm{CuCl}_{2}$ (Figure S2); bright field (a) and dark field (b) images (100×, 0.9 NA objective) of neural derived-ES cells incubated with $\mathrm{Cu}^{0}-\mathrm{AuNPs}$ or L1@ $\mathrm{Cu}^{2+}-$ AuNPs (250 nM) (Figure S3); bright field (a) and dark field (b) images (100×, 0.9 NA objective) of neural derived-ES cells incubated with $\mathrm{Cu}^{0}-\mathrm{AuNPs}$ or L1@ $\mathrm{Cu}^{2+}-$ AuNPs (750 nM) (Figure S4) (PDF)

\section{AUTHOR INFORMATION}

\section{Corresponding Authors}

*E-mail: luca.destefano@na.imm.cnr.it (L.d.S.).

*E-mail: jolanda.spadavecchia@univ-paris13.fr (J.S.).

\section{ORCID 8}

Luca de Stefano: 0000-0002-9442-4175

Raphaël Tripier: 0000-0001-9364-788X

Jolanda Spadavecchia: 0000-0001-6697-1174

\section{Author Contributions}

The manuscript was written through contributions of all authors. All authors have given approval to the final version of the manuscript.

\section{Notes}

The authors declare no competing financial interest.

\section{ACKNOWLEDGMENTS}

With the support of SATT IDF Innov, J.S. has filed a patent application on the nanoparticles presented in this manuscript $\left(\mathrm{Cu}^{0}-\mathrm{AuNPs}\right)$. Nanomaterial and method of production of a nanomaterial for medical applications, such as MRI or SERSInventor: J.S., European Patent Application number EP17305087.3, filed January 27, 2017, and PCT application PCT/EP2018/051988 filed January, 26, 2018. This work has been partly performed on the CNano Mat platform of the University Paris 13 . This work was partially funded by Italian Ministry of Health "Ricerca Corrente", PONPE_00060_7 and PONPE_00060_3 to S.F. The authors acknowledge the Integrated Microscopy Facility at Institute of Genetics and Biophysics "Adriano Buzzati Traverso", CNR in Naples for optical and confocal microscopy.

\section{REFERENCES}

(1) Miller, M. R.; Raftis, J. B.; Langrish, J. P.; McLean, S. G.; Samutrtai, P.; Connell, S. P.; Wilson, S.; Vesey, A. T.; Fokkens, P. H. B.; Boere, A. J. F.; Krystek, P.; Campbell, C. J.; Hadoke, P. W. F.;
Donaldson, K.; Cassee, F. R.; Newby, D. E.; Duffin, R.; Mills, N. L. ACS Nano 2017, 11, 4542-4552.

(2) Boonruamkaew, P.; Chonpathompikunlert, P.; Vong, L. B.; Sakaue, S.; Tomidokoro, Y.; Ishii, K.; Tamaoka, A.; Nagasaki, Y. Sci. Rep. 2017, 7, No. 3785.

(3) Chatterjee, A. K.; Chakraborty, R.; Basu, T. Nanotechnology 2014, 25, No. 135101.

(4) Henkel, A.; Jakab, A.; Brunklaus, G.; Sönnichsen, C. J. Phys. Chem. C 2009, 113, 2200-2204.

(5) Shokeen, M.; Anderson, C. J. Acc. Chem. Res. 2009, 42, 832841.

(6) Rout, L.; Kumar, A.; Dhaka, R. S.; Reddy, G. N.; Giri, S.; Dash, P. Appl. Catal., A 2017, 538, 107-122.

(7) Cai, Z.; Anderson, C. J. J. Labelled Compd. Radiopharm. 2014, 57, 224-230.

(8) Lu, H. D.; Wang, L. Z.; Wilson, B. K.; McManus, S. A.; Jumai'an, J.; Padakanti, P. K.; Alavi, A.; Mach, R. H.; Prud'homme, R. K. ACS Appl. Mater. Interfaces 2018, 10, 3191-3199.

(9) Mewis, R. E.; Archibald, S. J. Coord. Chem. Rev. 2010, 254, $1686-1712$.

(10) Odendaal, A. Y.; Fiamengo, A. L.; Ferdani, R.; Wadas, T. J.; Hill, D. C.; Peng, Y.; Heroux, K. J.; Golen, J. A.; Rheingold, A. L.; Anderson, C. J.; Weisman, G. R.; Wong, E. H. Inorg. Chem. 2011, 50, 3078-3086.

(11) Wong, E. H.; Weisman, G. R.; Hill, D. C.; Reed, D. P.; Rogers, M. E.; Condon, J. S.; Fagan, M. A.; Calabrese, J. C.; Lam, K.-C.; Guzei, I. A.; Rheingold, A. L. J. Am. Chem. Soc. 2000, 122, 1056110572.

(12) Weisman, G. R.; Rogers, M. E.; Wong, E. H.; Jasinski, J. P.; Paight, E. S. J. Am. Chem. Soc. 1990, 112, 8604-8605.

(13) Lima, L. M.; Halime, Z.; Marion, R.; Camus, N.; Delgado, R.; Platas-Iglesias, C.; Tripier, R. Inorg. Chem. 2014, 53, 5269-5279.

(14) You, J.; Zhang, G.; Li, C. ACS Nano 2010, 4, 1033-1041.

(15) Spadavecchia, J.; Movia, D.; Moore, C.; Maguire, C. M.; Moustaoui, H.; Casale, S.; Volkov, Y.; Prina-Mello, A. Int. J. Nanomed. 2016, 11, 791-822.

(16) Moustaoui, H.; Movia, D.; Dupont, N.; Bouchemal, N.; Casale, S.; Djaker, N.; Savarin, P.; Prina-Mello, A.; de la Chapelle, M. L.; Spadavecchia, J. ACS Appl. Mater. Interfaces 2016, 8, 19946-19957.

(17) Monteil, M.; Moustaoui, H.; Picardi, G.; Aouidat, F.; Djaker, N.; de La Chapelle, M. L.; Lecouvey, M.; Spadavecchia, J. J. Colloid Interface Sci. 2018, 513, 205-213.

(18) Fico, A.; Paglialunga, F.; Cigliano, L.; Abrescia, P.; Verde, P.; Martini, G.; Iaccarino, I.; Filosa, S. Cell Death Differ. 2004, 11, 823831.

(19) Ly, N. H.; Nguyen, T. D.; Zoh, K. D.; Joo, S. W. Sensors 2017, 17, No. 2628.

(20) Emmenegger, F. P.; Rohrbasser, C.; Schläpfer, C. W. Inorg. Nucl. Chem. Lett. 1976, 12, 127-131.

(21) Pal, U.; Sanchez Ramirez, J. F.; Liu, H. B.; Medina, A.; Ascencio, J. A. Appl. Phys. A 2004, 79, 79-84.

(22) Nguyen, M. T.; Zhang, H.; Deng, L.; Tokunaga, T.; Yonezawa, T. Langmuir 2017, 33, 12389-12397.

(23) Marguerit, G.; Moustaoui, H.; Haddada, M. B.; Djaker, N.; de la Chapelle, M. L.; Spadavecchia, J. Part. Part. Syst. Charact. 2018, 35, No. 1700299.

(24) Politi, J.; De Stefano, L.; Longobardi, S.; Giardina, P.; Rea, I.; Methivier, C.; Pradier, C. M.; Casale, S.; Spadavecchia, J. Colloids Surf., B 2015, 136, 214-221.

(25) Spadavecchia, J.; Apchain, E.; Alberic, M.; Fontan, E.; Reiche, I. Angew. Chem., Int. Ed. 2014, 53, 8363-8366.

(26) Lu, H. D.; Wang, L. Z.; Wilson, B. K.; McManus, S. A.; Jumai'an, J.; Padakanti, P. K.; Alavi, A.; Mach, R. H.; Prud'homme, R. K. ACS Appl. Mater. Interfaces 2018, 10, 3191-3199.

(27) Gammage, M. D.; Stauffer, S.; Henkelman, G.; Becker, M. F.; Keto, J. W.; Kovar, D. Surf. Sci. 2016, 653, 66-70.

(28) Gautier, J.; Allard-Vannier, E.; Munnier, E.; Souce, M.; Chourpa, I. J. Controlled Release 2013, 169, 48-61. 
(29) Lee, K. Y. J.; Wang, Y.; Nie, S. RSC Adv. 2015, 5, 6565165659.

(30) Sajanlal, P. R.; Sreeprasad, T. S.; Samal, A. K.; Pradeep, T. Nano Rev. 2011, 2, No. 5883.

(31) Toma, H. E.; Zamarion, V. M.; Toma, S. H.; Araki, K. J. Braz. Chem. Soc. 2010, 21, 1158-1176.

(32) Prabhu, B. M.; Ali, S. F.; Murdock, R. C.; Hussain, S. M.; Srivatsan, M. Nanotoxicology 2010, 4, 150-160.

(33) Liu, Z.; Shichang, L.; Guogang, R.; Taoc, Z.; Zhuo, Y. J. Appl. Toxicol. 2011, 31, 439-445.

(34) Bondarenko, O.; Juganson, K.; Ivask, A.; Kasemets, K.; Mortimer, M.; Kahru, A. Arch. Toxicol. 2013, 87, 1181-1200. 